\title{
Identifying and Prioritizing Factors Affecting the Innovation Process inNew Product Development Using Fuzzy Multi- Criteria DecisionMaking Techniques (A case study: Food Industry Companies of Sistan and Baluchestan)
}

\author{
Mohammad Reza Shahraki ${ }^{1^{*}}$, FarzadFadaei ${ }^{2}$ \\ ${ }^{1}$ Assistant Professor, Department of Industrial Engineering, University of Sistan and Baluchestan \\ mr.shahraki@eng.usb.ac.ir \\ ${ }^{2}$ Master Students of Civil Engineering, University of Sistan and Baluchestan
}

\begin{abstract}
Population growth and increased food consumption have led to an increase in demand. The development of a new food product will be driven by the application of a process-oriented method of transforming ideas into products to improve market development. This research identified and prioritized factors affecting the innovation process in developing new products in entrepreneurial companies active in the food industry of Sistan and Baluchestan province. The survey population included managers and entrepreneurial companies active in the food industry of Sistan and Baluchistan province. Criteria and options related to the development of a new product have been identified by a survey of industry experts and academic professors and have been ranked with the help of Fuzzy Hierarchy Process Analysis process. The results of the research showed that development, conceptual design, prototyping, mass production and marketing and sales were the most important factors in the development of new products, respectively .
\end{abstract}

Key words: New product development, Entrepreneur, Food industryInnovation, Analytical hierarchy process

\section{1-Introduction}

The dynamicity and complexity of the concept of new product development, competitiveness of organizations as well as the emergence of science and production processes have caused new challenges in producing new products. Some researchers argue that the development of a new product is an important factor in the production of wealth in a country. However, unfortunately the importance of the new product development is not associated with the level of its success and the risk of failure in the development of new products is high (Seyed Hosseini and Iranban, 2004). The primary solutions for the food shortage problem in the past was to more cultivate and exploit the reserves, but the competition for land, owing to other human activities, has made this solution costly (Balmford\& Green, 2005).

Based on these conditions, many researchers active in the food area try to improve the production and development of food products using modern technologies. The development of a new product in the food industry is considered as a crucial part of the business strategy. The development of innovation in the food industry through the development of new products is essential for each company and requires high investment in financial and human resources areas (Fuller, 1994). The process of product development in the food industry should be fast and flexible given the rapid changes in market and technology. The companies active in the food industry prefer to develop existing products with gradual innovation rather than creating entirely new products through fundamental innovations. The reason behind is that investment in food product development is associated with risk and the use of gradual innovation would increase the success rate and reduce the risk (Winger and Wall, 2006).

Hence, managers are interested in learning about the factors influencing the success of a new product. This research was conducted to identify and rank the factors influencing the innovation process in new products 'development in entrepreneurial companies active in the food industry. The next section of this research investigated theoretical foundations and research literature.Moreover, the third section presented theoretical frameworks and the conceptual model of the research. The fourth section presented the methodology of the research based on the fuzzy AHP method and the analysis of the data and the fifth section reported the conclusion and recommendations. 


\section{2-Review of theoretical foundations and research literature}

Many definitions have been presented regarding a new product development. Each of these definitions emphasizes the particular aspect of new product development. Some emphasize the adaptability of the organizational strategies to product development to satisfy the customer (Radford and Bean, 2000). Some of them also emphasize the production and operations for transforming the ideas into physical products (Semremata, 1999) and some others emphasize the planning early stage of new product development to ensure product success (Cagan and Vogel, 2002). Regardless of the emphasis on a specific stage of the new product process, the new product development process can be viewed as a process which transforms ideas into valuecreating products for customers (Belz, 2011). The new product development process involves all activities performed by the company in the development and launching new products (Bhuiyan, 2011). Loch and Kavadias (2008) viewed the development of new products as activities in the company leading to the flow of new or modified products to be presented in the market over time. These activities included creating opportunities, selecting among them and transferring them to customers and the institutionalization of the modifications in new product development activities.

New product development would result in responding to customers' needs, adapting to market conditions and environmental changes, increased profits, customer satisfaction, and coping with competitors' policies (Barclay and Dann, 2000). Ulrich and Eppinger(2004)have defined the product development as a set of activities which begin with recognizing the market and end with the production, sale, and delivery of the products. Wheelwright and Clark (1992) consider the new product development as organizing and effectively managing activities which enables the organization to offer successful products with a short development and low development costs to the market. Based on the authors, new product development process consists of several steps. According to Cooper and Kleinschmid (1986), this process consists of thirteen consecutive steps.According toStefanovitz and Nagano (2010), it consists of four steps. According toThieme et al. (2003), the new product development process consists of eight steps. Regardless of the names given to these steps and activities, there is a consensus among researchers that it includes the marketing and technical activities (Song, Parry, 1997). Marketing is a social and management process in which people and groups provide their needs through the creation and exchange of useful and valuable products (2008, Kotler \& Armstrong). Marketing and sales generally have common goals in recognizing the customer needs and solving their problems through providing more value to customers compared to competitors (LeMeunier-FitzHugh\& Piercy, 2007). Many researchers such as Cooper (2005), Wind (1982), Ulrich and Eppinger (1995) tried to develop a model to include the steps related to new product development process. Due to the diversity of views presented on new product development models and its steps, table 1 provides a summary of various models presented in this regard.

Table 1- Different models of the new product development process

\begin{tabular}{|c|l|}
\hline Researcher & \multicolumn{1}{|c|}{ Steps of the process } \\
\hline Kotler (2008) & $\begin{array}{l}\text { 1-Creating ideas 2. Screening the idea 3. Concept development and its } \\
\text { testing 4. Marketing strategy development 5. Market analysis 6. Product } \\
\text { development 7. Market testing 8. commercialization }\end{array}$ \\
\hline Cooper (2005) & $\begin{array}{l}\text { 1-Targeting 2. Creating business case 3. Development 4. Testing and } \\
\text { validation 5. Launching }\end{array}$ \\
\hline $\begin{array}{c}\text { Marion and } \\
\text { Simpson (2009) }\end{array}$ & $\begin{array}{l}\text { 1-Ideas / creativity 2. Initial evaluation 3. Innovation project 4. } \\
\text { 6esigning and testing the samples 5. Testing and validatingthe products }\end{array}$ \\
\hline $\begin{array}{c}\text { Biglliardi et al. } \\
\text { (2010) }\end{array}$ & $\begin{array}{l}\text { 1-Identifying the market`s needs and creating product ideas. 2. Creating a } \\
\text { technological solution. 3. Initial testing of product with selected customers. } \\
\text { 4. Product production and launching in the market. 5. Expanding it in } \\
\text { different markets }\end{array}$ \\
\hline
\end{tabular}

According to Shepherd and Ahmed (2000), the strong orientation of market, a deep understanding of consumers` needs and demands, a superior and unique product (high-performance product relative to cost), a strong market by allocating resources to marketing / promotion activities, attractive markets, high demand level, great and growing market, and non-competitive market, synergy in areas such as technology and marketing, high management support and good internal and external communication are among the key determinants of success in the new product development process.Reviewing the research conducted in this area, factors influencing the success of the development of the new product from the viewpoint of various authors in the area of food industry are presented in Table (2). 
Table 2- Factors influencing the success of new product development in the food industry

\begin{tabular}{|c|l|}
\hline New author & \multicolumn{1}{|c|}{ Factors influencing the success of new product development } \\
\hline Biglliardi et al. (2010) & $\begin{array}{l}\text { Separation 2. Customer voice 3. Market launching 4. Innovation protection } \\
\text { mechanisms 5. Reducing the time of product introduction to market }\end{array}$ \\
\hline $\begin{array}{c}\text { Fritz and Schiefer } \\
\text { (2008) }\end{array}$ & $\begin{array}{l}\text { 1-Increasing the profits relative to costs. 2. Community considerations. } 3 . \\
\text { Benchmarking research }\end{array}$ \\
\hline Rontelta et al (2007) & $\begin{array}{l}\text { Technical feasibility 2. Marketing feasibility } \\
\text { 3. Political feasibility 4. Approval of laws } \\
\text { 5. Customer acceptance }\end{array}$ \\
\hline Yang (2006) & $\begin{array}{l}\text { Implementation of the project strategy underfour categories of separation, cost, } \\
\text { operation and quality }\end{array}$ \\
\hline Mu et al. (2007) & Technological, marketing, management and commercialization factors \\
\hline $\begin{array}{c}\text { Sun and Wing } \\
\text { (2005) }\end{array}$ & $\begin{array}{l}\text { Clear definition of target market, the use of standard quality, project goals, } \\
\text { internal communication with the project team, timely delivery of the product } \\
\text { to customers, the right launching time, the competitive cost of the product }\end{array}$ \\
\hline
\end{tabular}

\section{3-Research method}

The objective of this study was to identify and rank factors influencing the innovation process in new products` development in entrepreneurial companies active in the food industry based on different steps of product development. The conceptual model of the factors influencing the innovation process in the new product development is presented in Figure 1. This model was designed using previous studies. In addition, hierarchical analysis was used in new product development .According to the past studies and the views of experts, five key factors influencing the new product development process were identified. These five factors included the concept of a new product development, the design of a new product, the production of a prototype of new product, the mass production, marketing and sales network. Moreover, three criteria including the time of effect on innovation process, the range of effect on the innovation process and the intensity of the effect on the innovation process were used to determine the importance of each of the factors.

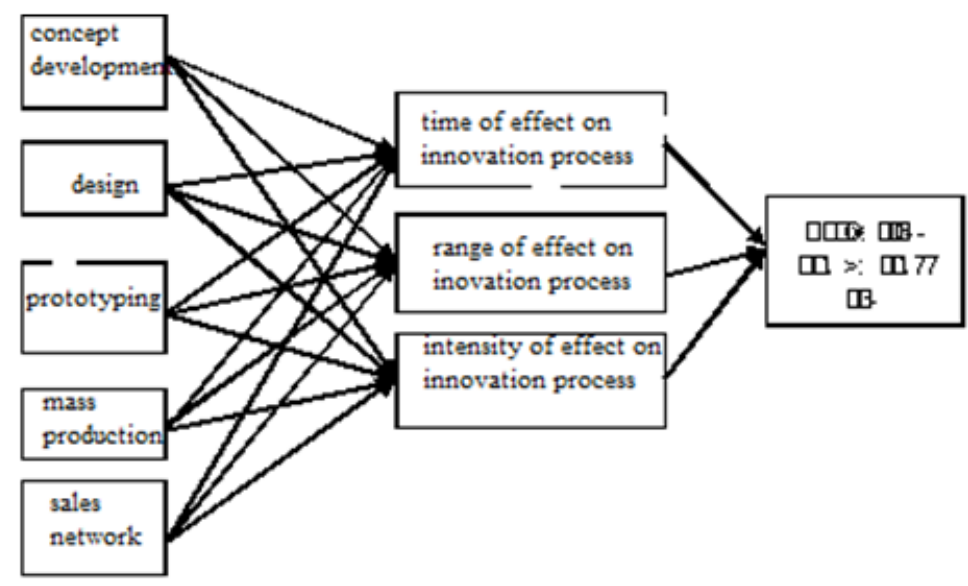

Innovation process of developing new product

Figure 1- Conceptual model of factors influencing the innovation process in new product development based on AHP method

\section{4-Rsearch Methodology}

The objective of this study was to analyze the factors influencing the innovation process in the new products development in entrepreneurial companies active in the food industry. The present study was a survey research with an applied nature.Therefore, the results of this research can be applied in other sectors active in this area. The research was causal sinceits objective was to evaluate the effect of the factors influencing the innovation process on the new products` development.Moreover, the research was a survey type of study since the field method was used to collect the data and analyze them for the aim of identification and determining the effect of the factors influencing the innovation process in the new products development. This research aimed to identify and rank the factors influencing the innovation process in new products development. This research was conducted in two steps. 
In the first step, the factors influencing the innovation process in the new product development were identified using the articles and library resources and interviewing with experts and managers of the entrepreneurial companies which were active in the food industry. In the second step, the identified factors were ranked through a questionnaire and multi-criteria decision making methods known as Analytic Hierarchy Process (AHP). Analytic Hierarchy Process is one the multiple-criteria decision making methods. This method makes it possible to formulate the problem in a hierarchical manner. It also has the ability to consider quantitative and qualitative criteria in the problem.Moreover, this method is based on a paired comparison facilitating judgment and calculations. Another advantage of hierarchical analysis process is that it provides a framework for team cooperation and involvement in decision making and problem solving. To solve the problem through AHP, the problem needs to be defined and designed as a hierarchical structure. The first level represents the objective of decision making and the final level represents the options compared with each other. Intermediate levels also represent factors considered as criteria for comparing the options.

\section{4-1-Research population and sampling method}

The research population was classified into two general groups qualitatively. The first group included those who have academic experience in the development of a new product and the second group included those who already had work experience in the area. Quantitatively, the research population included experts and senior managers of entrepreneurial companies active in the food industry. Sampling method was used in this study. Sample: Sample is a part of the studied population in a pre-defined manner. In sampling, usually a small sample of whole population is determined and its results are generalized to the whole population. To this end, a questionnaire was sent to 10 experts, 6 of which were received. Finally, 4 questionnaires were used .

\section{4-2- Data collection instrument}

Questionnaires were used to obtain the views of expert on the paired comparison matrix. The questionnaires were designed in a way that they allowed respondents to determine the criteria and sub-criteria and importance of each of them using paired comparison. To evaluate the validity of the questionnaire, the views of the experts and senior managers of the entrepreneurial companies, active in the food industry and university professors were used. Moreover, in order to measure the reliability of the questionnaire, the inconsistency rate (which should be more than 0.1) was used based on Table 3. After collecting the answers of the experts in the form of verbal items, these answers had to be converted to fuzzy scale. The scale used in this study was a nine-item fuzzy scale (Table 3).

Table 3- The fuzzy spectrum and corresponding verbal phrases

\begin{tabular}{|c|c|c|}
\hline Types of preferences & Fuzzy number & Symbol \\
\hline Not important & $\left(0.0,0.1^{)}\right.$ & $\mathrm{u}$ \\
\hline Less important & $(0,0.3,0.3)$ & LI \\
\hline Relatively less important & $(0.1,0.3,0.5)$ & FLI \\
\hline moderate & $(0.3,0.5,0.7)$ & $\mathrm{N}$ \\
\hline Relatively important & $(0,5,0,7,0,9)$ & FI \\
\hline Important & $(0.7,0.8,0.9)$ & I \\
\hline Very important & $(0.9 .1 .1$ & VI \\
\hline
\end{tabular}

\section{Fuzzy AHP Analysis}

Analytic Hierarchy Process (AHP) is one of the multi-criteria decision making technique presented by Saaty (1980). This technique can be used when the decision making action is faced several options and criteria. Criteria in decision-making can be quantitative or qualitative. Decision-making is based on paired comparisons. The process of decision-making starts with providing a decision-making hierarchy tree. Then, paired comparisons are performed between the criteria. These comparisons determine the weight of each criteria in line with rival options. Finally, it integrates the matrices derived from the paired comparisons leading to optimal decisions (Azar, 1994).

The Fuzzy Analytic Hierarchy Process (FAHP) is a classic fuzzification method based on fuzzy numbers and calculations (Azar and Faraji, 2010). Chang (1992) presented a very simple method to extend the hierarchical analysis process into a fuzzy space. This method is based on the arithmetic mean of experts' views and the Saaty normalized method (1980) and it has been developed using fuzzy triangular numbers (Zanjirchi, 2011). 
The steps of this method are as follows:

Step 1: Drawing a hierarchical tree

In this step, a hierarchical decision making structure is drawn using the levels of objectives, criteria, and options.

Step 2: Creating a pairwise comparisons matrix

In this step, the agreement matrices are formed according to the decision making tree and using experts' views. Then, inconsistency rate is calculated according to the Gogus\& Boucher method (1998).

Step 3: The calculation arithmetic mean of the views

Step 4: The sum of the elements of the row is calculated

Step 5: Normalizing the weights of the rows

Step 6: Determining the degree of larger probability

Step 7: Normalizing the vector of weights

Step 8: Combining the weights in order to obtain the priorities (Zanjirchi, 2011).

\section{4-3- Fuzzy Analytical Hierarchy Process Using Chang Method}

Using the hierarchical structure (Figure 2) and following the steps of the fuzzy hierarchical process analysis process, the views of experts is obtained through the transformation of verbal expressions into triangular fuzzy numbers with respect to aggregation. To ensure the consistency of the matrices, the inconsistency rate is calculated according to the Gogus\& Boucher method (1998). Then, the weight of each criterion of level 2 and level 3 of hierarchical structures are calculated.

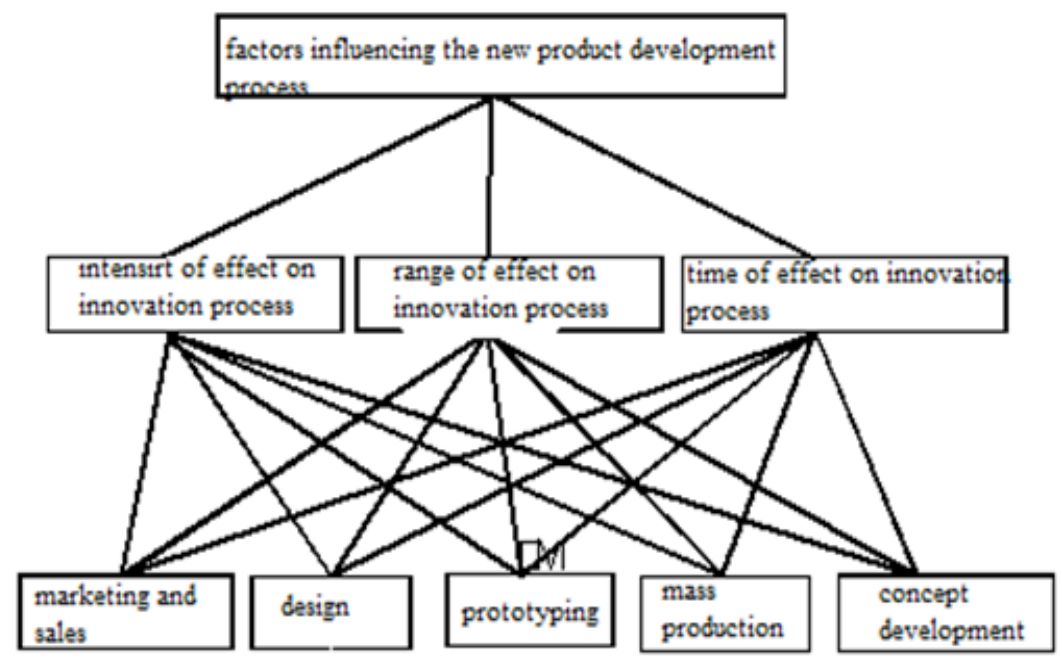

Figure 2- Hierarchical tree of factors influencing the new product development process

Table 4- Relative and final weights of criteria

\begin{tabular}{|c|c|}
\hline Criterion & Weight \\
\hline Time of effect on innovation process & 1.2 \\
\hline Range of effect on innovation process & 1.01 \\
\hline Intensity of effect on innovation process & 1.13 \\
\hline
\end{tabular}

As seen in Table (4), among the criteria influencing the innovation process in the new product development, the time of effect on innovation process hadthe highest weight.Then, the intensity of effect on innovation process, and the range of effect on the innovation process have the highest weights. 
Table 5- General ranking of factors influencing innovation process in new product development

\begin{tabular}{|c|c|}
\hline factors & Weight \\
\hline Concept development & 0.62 \\
\hline Mass introduction & 0.86 \\
\hline Prototyping & 0.64 \\
\hline Designing & 0.32 \\
\hline Marketing and sale & 0.89 \\
\hline
\end{tabular}

The effect of the general factors influencing the innovation process in new product development based on the hierarchical analysis method is listed in Table 5. As shown in Table (5), among the factors influencing the innovation process in developing a new product, marketing and sales have had the greatest impact on the innovation process in the development of new products, and then, mass production, sampling, development of the concept and design had the highest effects on the innovation process in new products development .

\section{5-Discussion and conclusion}

The results of the qualitative research in this paper suggested that the new product development process in the entrepreneurial companies active in the food industry in Sistan and Baluchestan province included five main steps. These five steps were the concept development, design, prototyping, mass production, and sales and marketing which confirms the dimensions and steps of the Ulrich and Eppinger (1995). Having reviewed the history of research and interviewing with managers and experts in the field of new product development and using a comprehensive theoretical framework, the main and the secondary factors affecting the step of the new product development process have been comprehensively identified. In addition to identification, the present study identified and ranked these factors, which can guide managers in paying attention to the importance of each of these factors for new product development.

Research and development of new products for various types of production and service organizations was considered as competitive advantage. The issue regarding which percentage of organizational activities is spent on research and development of new products,was related to current and strategic position of organization in demand market. This study examined factors affecting the process of innovation in new product development. The results indicated that many factors affected the process of innovation in new product development, including the concept development factors, design, prototyping, mass production and marketing and sales. The results of this research confirmed that the marketing and sales agent were of utmost importance.

Based on the results of this article, it is recommended that companies active in this area can determine the strategies of new product development accurately. The best new product development strategies in entrepreneurial companies active in food industries include research and development strategy, transfer of technology, and alliance with one domestic and foreign company. When establishing a company, it is recommended to conduct a research on the market,technology, finance and economy. It is recommended to analyze the conceptual model of the new product development process using structural equation modeling.Having applied it in a company context, an appropriate model for the new product development process can be obtained and tested.

\section{References}

[1] Seyed Hosseini, SM., Iranban, SJ (2004), Strategies for the Development of New Product, Approaches and Results, Management Knowledge Magazine, Issue 64, Tehran

[2] Zanjirchi, SM (2011), Fuzzy Analytical Hierarchy Process, Tehran: SaneiShahmirzadi Azar, Faraji (2010), Fuzzy Management Science, Tehran: Mehreban Publications.

[3] Azar, A (1994), Knowledge and Management Quarterly, Issue 27, Spring 1994, Issue 28, Winter 1994, 23 Balmford, R. E., Green, J. P. W., (2005). Scharlemann, Global Change Biol, 11, 1594.

[4] Barclay, I., Dann, Z. (2000). New-Product-Development Performance Evaluation: A Product-Complexity-Based Methodology, IEE Proc. -Sci. Meas. Technol., 147(2), 41-55.

[5] Bean, R., Radford, R. (2000). Powerful products, strategic management of successful new products development, New York, AMACOM, 33-109.

[6] Belz, A. (2011). Product development, Mc Graw Hill Publishing, 8

[7] Bigliardi, B., Bottani, E., Montanari.,Vignali. (2010). Successful new product development in the food packaging industry: evidence from a case study, International Journal of Engineering, Science and Technology, 2(9), 13-24.

[8] Bhuiyan, Nadia. (2011). A framework for successful new product development, Journal of Industrial Engineering and Management, 4(4), 746-770.

[9] Crawford, C. (1987). New product management, (2nd Ed. \& 5th Ed.), Illinois: Richard D. Irwin.

[10] Cagan, J., Vogel, C. (2002). Creative break through products, Upper Saddle River, Prentice Hall

[11] Chang, D. Y. (1992). Extent Analysis and Synthetic Decision, Optimization Techniques and Applications. World Scientific, Singapore, 1, 352

[12] Cooper, R.G. (2005). Product Leadership: Pathways to Profitable Innovation. (2nd ed.), New York, NY: Perseus Books 
[13] Cooper, Kleinschmidt. (1986). An investigation into the new product process: steps, deficiencies, and impact. J. Prod. Innov. Manag, 3, 71-85

[14] Fuller, G.W. (1994). New food product development from concept to market place, USA: CRC Presss, 257

[15] Fritz,M., Schiefer,G. (2008). Food Chain Management for Sustainable Food System Development: A European Research Agenda, Agribusiness, 24(4), 440-452.

[16] Gogus O., Boucher T. (1998). Strong transitivity, rationality and weak monotonicity in fuzzy pairwise comparisons, Fuzzy Sets and Systems, 94(1), 133-144.

[17] Kotler, P., Armstrong, G. (2008). Principles of Marketing. 12thed, New Jersey :Prentice Hall

[18] LeMeunier-FitzHugh, K., Piercy, N.F. (2007). Exploring collaboration between sales and marketing. European Journal of Marketing, 41(7/8), 939-955.

[19] Loch,Ch., Kavadias,S. (2008). Handbook of New Product Development Management, Printed and bound in Hungary

[20] Mariona., Simpson. (2009). New product development practice application to an early-stage firm: the case of the PaperPro® StackMasterTM, Design Stud, 30, 561-587.

[21] Mu, J., Peng, G., Tan, Y. (2007). New product development in Chinese SMEs Key success factors from a managerial perspective, International Journal of Emerging Markets, 2 (2), 123-143.

[22] Ronteltap, A., van Trijp, J.C., Renes, R.J., Frewer, L.J. (2007). Consumer acceptance of technology-based food innovations: lessons for the future of nutrigenomics, $49,1-17$.

[23] Saaty., Thomas, L. (1980). The Analytic Hierarchy Process: Planning, Priority Setting, Resource Allocation, Pittsburgh: RWS Publications.

[24] Stefanovitz, J.P., Nagano, M.S., (2010). Product innovation management: an integrated model proposal. Prod, 24(2), 462-476.

[25] Shepherd, C., Ahmed, P.K. (2000). From product innovation to solutions innovation :a new paradigm for competitive advantage, European Journal of Innovation Management, 3(2), 100-106.

[26] Sheremata, W. (1999). Implementing strategies of radical new product development ,Ph.D Thesis New York University

[27] Song, X.M., Parry, M. (1997). The determinants of Japanese new product success, Journal of Marketing Research, 34(1), 64-76.

[28] Sun, H., Wing, W.C. (2005). Critical success factors for new product development in the Hong Kong toy industry, Technovation, 25, 293-303

[29] Thieme, S.S. (2003), Project management characteristics and new product survival, J .Prod. Innov. Manag, 20, 104-119

[30] Ulrich, K.T., Eppinger, S.D. (1995). Product Design and Development. McGraw-Hill, New York Winger, R., Wall, G. Food product innovation. A background paper, FAO 2006

[31] Wind, Y. (1982). Product policy: Concepts, methods, and strategy. Reading, Mass: Addison-Wesley

[32] Wheelwright, S.C., Clark, K.B. (1992), Revolutionizing Product Development :Quantum Leaps in Speed, Efficiency and Quality, The Free Press, New York, NY.

[33] https://books.google.com/books

[34] Wheelwright, S.C., Clark, K.B. (1992), Revolutionizing Product Development: Quantum Leaps in Speed, Efficiency, and Quality, The Free Press, New York

[35] Yang, L. (2011). Implementation of project strategy to improve new product development performance, International Journal of Project Management, November 2011 